\title{
Raising Backyard Chickens for Eggs ${ }^{1}$
}

\author{
Mary E. Henry, Jessica M. Ryals, Alicia Halbritter, and Derek L. Barber ${ }^{2}$
}

Raising backyard chickens is an increasingly popular way to explore self-sufficiency, connect with how our food is produced, and gain experience for future dabbling in food production. Besides producing quality eggs to eat and share, raising chickens can be an enjoyable pastime for youth and adults alike. Those considering launching a small farm business including poultry may also be interested in starting with a few backyard hens to build their knowledge and experience. This publication is designed primarily for those considering raising backyard chickens for eggs for personal consumption. Resources for additional information on eggs for sale or larger scale production are also provided.

UF/IFAS Extension is a statewide partnership between the University of Florida and Florida's 67 counties. This publication addresses community need for research-based information in the area of food systems, one of the High Priority Initiatives of UF/IFAS Extension based on needs identified through citizen input.

\section{Check Your Local Ordinances}

Before getting started, consider whether or not it is legal to keep chickens where you live. Many communities have regulations that restrict the location and quantity of poultry on residential properties. These regulations are generally put in place to keep residential neighborhoods free of the noise, odors, pests, and predators associated with keeping poultry. Common restrictions include limiting the number of birds, establishing a setback from neighboring property for housing, and a general prohibition of male chickens, or roosters. Most prohibit roaming poultry and are often enforced based on complaint. These ordinances sometimes include an exemption for student educational projects. Note that while chickens may be permitted, other livestock of interest such as ducks or turkeys may not be allowed. Make friends with your neighbors and verify any regulations to protect yourself and your birds from any problems. To confirm your zoning designation, visit the website of your city or county's Planning and Zoning department or contact them directly. You can also search your local ordinances at https://library.municode.com/fl.

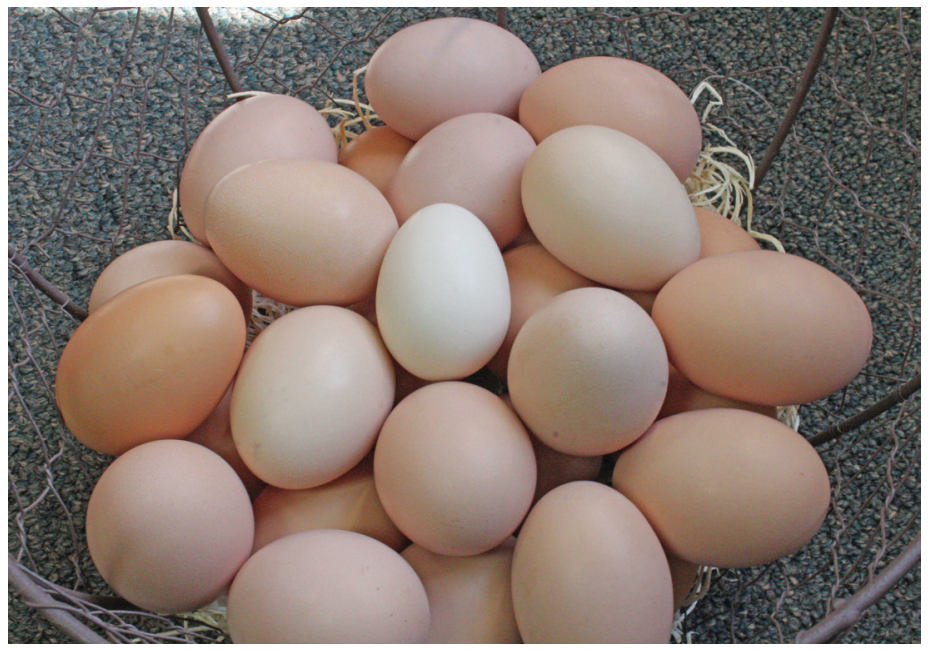

Figure 1. Backyard chickens can provide colorful eggs and companionship.

Credits: A. Halbritter, UF/IFAS

1. This document is AN239, one of a series of the Department of Animal Sciences, UF/IFAS Extension. Original publication date April 2010. Revised November 2019. Visit the EDIS website at https://edis.ifas.ufl.edu for the currently supported version of this publication.

2. Mary E. Henry, small farms Extension agent III, UF/IFAS Extension Polk County; Jessica M. Ryals, sustainable food systems Extension agent II, UF/IFAS Extension Collier County; Alicia Halbritter, agriculture and natural resources Extension agent I, UF/IFAS Extension Baker County; and Derek L. Barber, former livestock and natural resources Extension agent II, UF/IFAS Extension Columbia County; UF/IFAS Extension, Gainesville, FL 32611.

The Institute of Food and Agricultural Sciences (IFAS) is an Equal Opportunity Institution authorized to provide research, educational information and other services

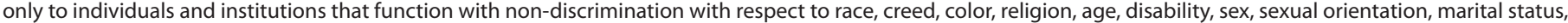
national origin, political opinions or affiliations. For more information on obtaining other UF/IFAS Extension publications, contact your county's UF/IFAS Extension office. U.S. Department of Agriculture, UF/IFAS Extension Service, University of Florida, IFAS, Florida A \& M University Cooperative Extension Program, and Boards of County Commissioners Cooperating. Nick T. Place, dean for UF/IFAS Extension. 


\section{Is this a 4-H or fair project?}

$4-\mathrm{H}$ is a Youth Development program conducted around the country through land-grant universities like the University of Florida. The program focuses on learning by doing, and raising chickens is one of the many experiential educational projects available to participants. Find out more about 4-H at http://florida4h.org/. Contact your local UF/IFAS Extension office to learn more about the program. See http://sfyl.ifas.ufl.edu/find-your-local-office/ for more information.

If your interest in raising backyard chickens is related to exhibiting in a fair or as part of a 4-H educational project, verify any specifics required to qualify before getting started. For example, the fair may require animals be recognized breeds rather than mixed or a breed not formally recognized. Visit your local fair for breed inspiration. Find a listing of fairs statewide at www.freshfromflorida. com and learn more about raising heritage breeds at https:// livestockconservancy.org/.

\section{Housing}

While social media may feature photos of extravagant chicken palaces, chicken coops do not need to be expensive or elaborate in Florida. Building your own can be a fun project and an opportunity to practice reusing and recycling materials. Kits and pre-assembled chicken coops are also readily available at many feed stores and other rural lifestyle suppliers. An area that is covered by a roof and enclosed with a minimum of two sides for protection from prevailing rain and wind is usually sufficient. The size of the house should be based on a minimum of $3 \mathrm{ft}^{2}$ of floor space per bird. Twenty-five birds with $3 \mathrm{ft}^{2}$ of floor space will require $75 \mathrm{ft}^{2}$ of floor space; a house that is $8 \mathrm{ft} \times 10 \mathrm{ft}$ will be sufficient for this example. The use of fencing (chicken wire) helps in confining the birds and provides protection from predators. The top of the enclosure also needs to be covered to prevent flying and climbing predators from entering. Find several design plans online at https://articles. extension.org/poultry.

If your coop will be visible from outside your property, consider its appearance and the impression it may leave on your neighbors. Your coop can be a bright spot in the neighborhood or a point of contention, largely based on its appearance and upkeep. Poultry housing structures may also fall under your county or city ordinance and have requirements for required setbacks or permits. Again, refer to your local ordinance to verify standards.

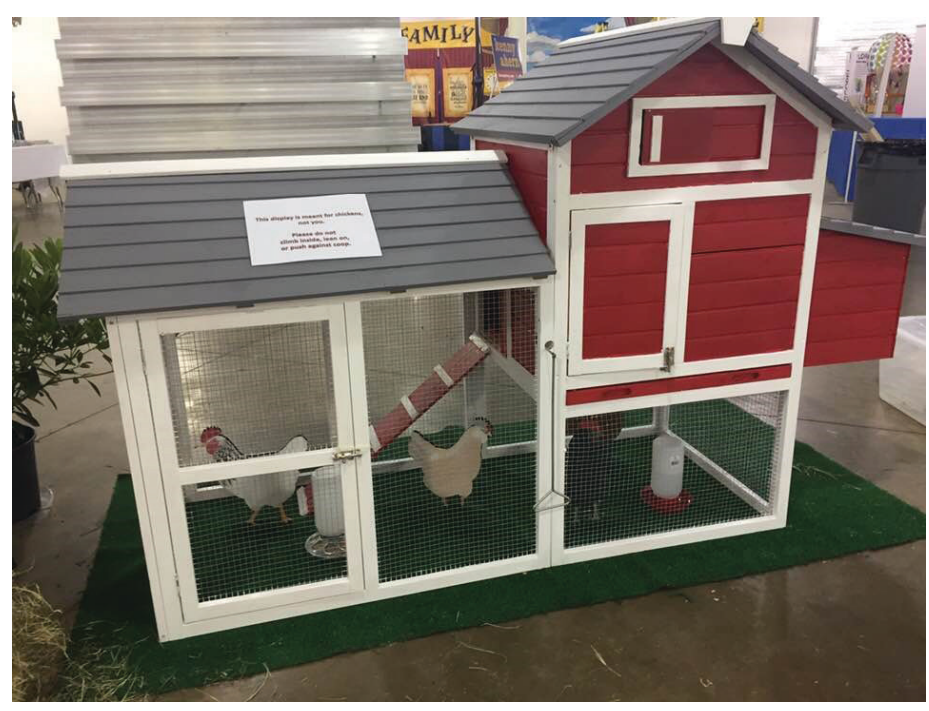

Figure 2. Attractive coops may be purchased or constructed. Credits: A. Halbritter, UF/IFAS

\section{Free Range, Mobile Coops, and "Chicken Tractors"}

Interest in supporting specific production practices has increased the number of terms used in the marketplace that can easily be a point of confusion. According to the USDA, "free range" means the animal has been allowed access to the outside. "Cage-free" indicates the birds have unlimited access to food and water and can roam their enclosure; however, they are not required to have access to the outdoors. For more information, see the USDA website (https://www.usda.gov/media/blog/2016/09/13/ usda-graded-cage-free-eggs-all-theyre-cracked-be).

Most backyard chicken enthusiasts want to allow their animals access to the outdoors during the day, with secured housing at night. Using an enclosed run, or additional protected yard space, provides an open area that reduces stress and pecking and will allow the birds to supplement their diets with greens and insects, which may reduce pests in your yard. Suggested run size is $8-10 \mathrm{ft}^{2}$ per bird. Those unfamiliar with raising chickens may be unaware that even just a few birds in an enclosed yard space can quickly lead to bare ground in the area due to their foraging behaviors.

Mobile coops or "chicken tractors" have become more popular as a way to allow access to forage with the ability to relocate the coop, reducing the stress on grass and more widely distributing the droppings of the birds. These coops may include a wheel to make moving the structures easier, or they may be designed to pull from one area to the next by other means. Mobile coops are required in some municipalities and can be a great way to meet the needs of the birds while protecting the grass. Monitor the condition of 
your grass to determine when to rotate the location of your mobile coop. Also note that the wider distribution of waste will increase the distribution of any pathogens it contains, such as Salmonella, which is commonly found in chicken droppings. Keep in mind that in the event of a hurricane or major weather event, mobile coops will need to be stored in an enclosed area to avoid becoming a hazard.

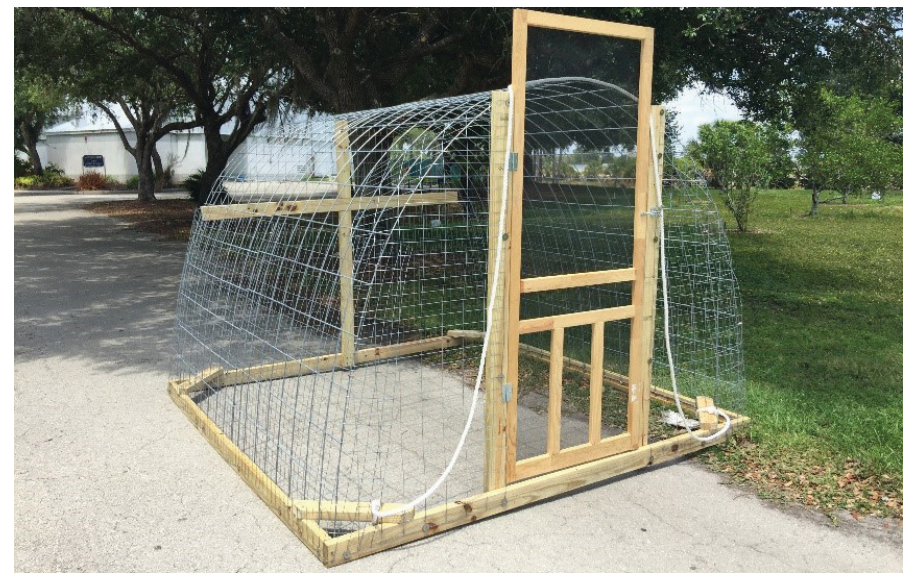

Figure 3. Mobile coops can help reduce damage to grass.

Credits: J. Ryals, UF/IFAS

\section{Predators}

Predators will be a risk factor for your birds. A mobile coop may increase vulnerability to predators, because they may more easily burrow under a mobile rather than stationary coop. You may experience a wide range of potential predators from dogs and cats to wildlife, such as hawks, owls, foxes, coyotes, raccoons, and opossums. Hardware cloth is screening similar to chicken wire, but it uses a tighter wire spacing pattern, reducing the opening size and better protecting your birds from smaller predators such as snakes, pests, or rats, which may be attracted to your bird's feed and eggs. It is recommended that stationary coops include chicken wire or other barriers buried 12-18 inches in an L-shape at the perimeter of the structure to deter predators from digging their way inside.

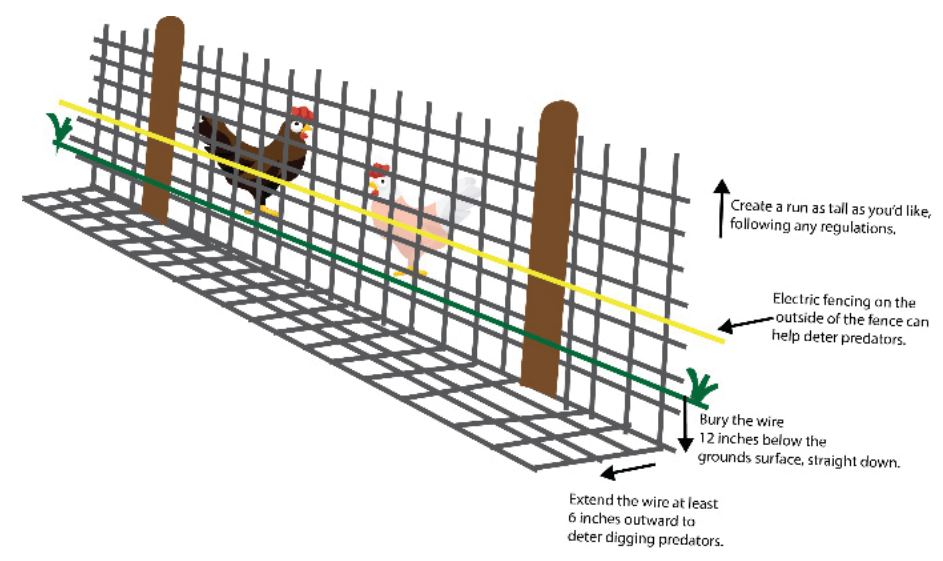

Figure 4. Bury fencing to prevent burrowing predators. Credits: A. Halbritter, UF/IFAS

\section{Nesting}

As the birds reach the age of 18-20 weeks, nesting boxes should be in place. Boxes that measure $12 \times 12 \times 12$ inches and are half filled with straw or wood shavings are ideal. Provide at least one nest box for every five hens in the flock, and place them about two feet above the ground. A perch may be placed in front of each box, allowing a spot for hens to land before entering the box. A wide range of materials may be creatively reused for nesting boxes, including repurposed buckets or milk crates.

\section{Choosing a Feed}

Good nutrition is very important in maintaining a healthy flock. Backyard enthusiasts may envision allowing yard access to meet a significant portion of nutritional needs; however, research has shown that only a small portion of the bird's basic nutritional needs may be met by foraging. Forage, scraps, or other supplements may displace feed intake, which can actually reduce or dilute the essential nutrition for healthy maintenance and growth. Providing free access to feed will ensure optimum growth and development. An estimated $70 \%$ of the cost of raising chickens can be attributed to feed; however, this is an investment rather than an expense. The better the birds are fed, the more productive they will be. Inadequate or dirty water, stale or rancid feed, mold, disease, and heat can inhibit feed and water intake. Additions of scraps and other supplements are addressed later in the publication.

Commercially available feed comes in three different forms: mash, crumble, and pellets. The shape of the feed does not affect the nutrition it provides, and determining which one to use is largely a matter of personal preference. Note that chickens do not have teeth and large pellets are not suitable for chicks due to the size. Pellets may reduce waste due to spills for larger birds. Experiment to see what works best for you.

Using the right feed for the growth stage and purpose of your birds is important. Starter and grower feeds contain a higher percentage of protein to meet the growth needs of young birds, and layer feeds contain the higher percentages of calcium necessary for egg production. If fed layer feed, chicks will develop kidney problems and rickets since chicks will not use the extra calcium, and the calcium to phosphorus ratio will be put out of balance. Expect reduced growth, unnecessary stress, and potentially higher mortality rates if layer feed is fed to chicks. Roosters should not consume layer feed, either, since they will not be using the extra calcium; only laying-age female poultry should 
consume layer feed. If you have a mixed species flock (e.g., guinea hens, turkeys, waterfowl, etc.), all-flock feed is available and formulated to provide for specific nutrient requirements for various species.

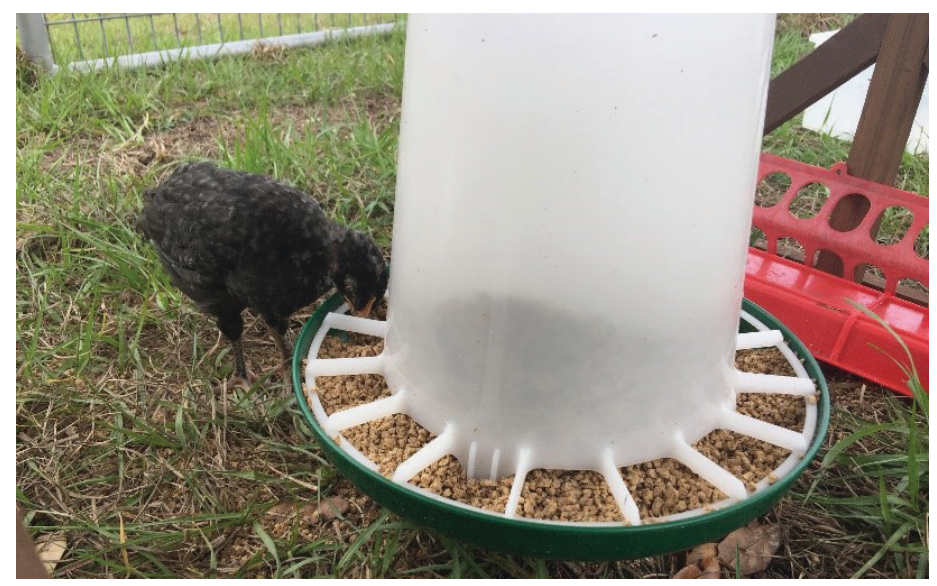

Figure 5. Commercial feeds are formulated to provide nutrition based on stage of growth.

Credits: J. Ryals, UF/IFAS

\section{Diet Transitions for Females Intended as}

\section{Layers}

\section{0-6 Weeks:}

- The starter diet for chicks has the highest level of protein a chicken will receive during its lifetime to support rapid growth. Newly hatched chicks will require a commercial starter feed (20-24\% protein) that is usually fed until six weeks of age. Expect to use at least four pounds of starter feed per bird.

\section{6-18 Weeks:}

- After six weeks, switch to a grower feed (16-20\% protein), and feed this up to 18 weeks of age. Many feed stores carry a combination starter/grower feed that will work well for both stages of growth. If the chicks are male, then they can be fed the same starter or starter/ grower feed as the females until six weeks of age and then switched to the grower feed indefinitely. Do not feed layer feed to males. If your flock includes males, an all-flock blended feed may be a good choice to reduce confusion and risks of imbalanced nutrition for parts of your flock.

\section{Weeks and Older:}

- At 18 weeks, switch to a layer feed (14-16\% protein) to prepare the birds for egg production. Layer feed normally contains approximately $3.5-4.0 \%$ calcium; however, birds less than 18 weeks old require only about $1 \%$ calcium in their diet. Do not feed layer feed to birds less than 18 weeks old or starter/grower feed to birds producing eggs, because there is inadequate calcium in starter/grower feeds to support egg production.
- Calcium (e.g., crushed oyster shell, ground or large particle limestone) and hard, insoluble granite, also called grit, may be mixed in a commercial feed or can be provided as a free-choice supplement.

- Note that calcium and grit are not the same. Grit is insoluble and stored in the gizzard of the bird where it is used to physically grind food during digestion, while calcium is soluble, absorbed, and metabolized for eggshell formation. Commercial feeds are designed to be highly digestible, which may reduce or eliminate the need for grit; however, birds with access to a wider-ranging diet (such as in backyard foraging) may take in less digestible food that may require grinding for adequate digestion. Your birds may also pick up small stones in your yard that may reduce the need for supplemental grit. During hot weather, chickens will generally consume less feed, and free-choice access to calcium will provide the calcium needed for quality eggs.

\section{Medicated Feed}

Coccidiosis is a disease caused by a microscopic parasite (protozoan) that infects the intestinal tract. Young birds are particularly susceptible to the disease. Commercial starter feeds may include medication to control coccidiosis and if so, they will be clearly labeled as medicated. Before choosing medicated feed, be sure to ask if the birds have already been vaccinated for coccidiosis. Medicated feeds counteract the live vaccine; therefore, do not use medicated feed for birds already vaccinated for coccidiosis. Booster vaccinations are not required. Grower and layer feed usually do not contain medication.

Non-medicated starter feed is available to use for those birds receiving a coccidiosis vaccination or for the poultry owner choosing a more organic production system. Chicks are particularly susceptible to coccidiosis because they have not yet built an immunity to infection. Over time, however, chickens will naturally develop immunity after exposure. Vaccination or medicated feed provides early protection during the most vulnerable stage of the bird.

Choosing not to vaccinate or use medicated feed will increase your flock's risk of illness and mortality. Note that the protozoan parasite that causes coccidiosis and its eggs are commonly found in the droppings of chickens and other birds. One reason wire floors are used in commercial poultry production is to improve sanitation and reduce the birds' exposure to their waste and any pathogens it may contain. While backyard chicken enthusiasts may not 
envision using wire floors, and prefer to avoid vaccinations or medicated feed, it is important to understand that these choices may leave your flock at increased risk of illness or higher mortality due to coccidiosis. For more information, see EDIS document PS47, Common Poultry Diseases (http://edis.ifas.ufl.edu/ps044) and EDIS document VM76, Intestinal Parasites in Backyard Chicken Flocks (http://edis. ifas.ufl.edu/vm015).

\section{Table Scraps and Other Supplements}

Use caution when offering scraps and other non-staple additions to your bird's diet. Note that these can affect the nutritional balance of their diet and may even increase stress due to limited digestibility of some foods. Note that digestion requires energy and generates heat. Foods that are not readily digestible for your birds may increase the risk of overheating, especially in high temperatures. Adding scratch or cracked corn to a well-balanced diet can be entertaining, but it does not provide the adequate protein and other nutrients needed by your birds and might be thought of as a treat rather than a staple of the diet. Birds consuming more grains will eat less of the complete nutrition provided by feed, reducing the overall nutritional value of the diet.

Poultry supplements are a point of discussion in online forums and magazines, but there is often a lack of scientific evidence to back up the claimed benefits of the suggested supplement. The role of UF/IFAS Extension is to share research-based information to help the public make decisions. Without validated research to anchor supplement recommendations, chicken enthusiasts should approach suggestions with skepticism to avoid adding expenses without seeing results.

The addition of vinegar to poultry water is often a point of interest. This practice is used in commercial meat-bird production to promote gram-positive bacteria and reduce Salmonella in the bird's crop. In some studies, vinegar has been shown to be effective in controlling certain bacteria; however, there is no scientific evidence to support this claim in live poultry (Griggs and Jacob 2005). Electrolyte supplements may also be a point of interest. These are additions to the water targeted to help with loss of electrolytes under high temperature conditions that can lead to dehydration. These supplements may help to reduce the effects of heat stress but are not necessary for the health of the bird as long as fresh, clean water is always available. Whenever a supplement is used, manufacturer instructions for dosing and length of administering should be followed.
Periodic interest has also been shown in growing various crops as a feed source or supplemental feed source for backyard chickens. There is not a lot of information on this practice for Florida, but national sustainable agriculture resources such as ATTRA may be helpful. See more about ATTRA at https://attra.ncat.org/.

\section{Organic Production}

Interest in organic production is on the rise. USDA organic certification is available, but it is not very practical for backyard production because of the certification costs involved. Organic livestock production requires 100\% certified organic feed, which is readily available at many feed stores but may be more expensive than conventional feed. Do not allow your chickens to forage in areas treated with herbicides or other pesticides not approved for organic production. Explore the USDA certified organic livestock standards at https://www.usda.gov/topics/organic.

If not planning to use organic practices, it is still important to note that any pesticides or fertilizer applied to your yard could be ingested by your birds. If pesticides or fertilizers are applied in your yard, be sure to follow any label instructions regarding safe reentry to a treated area. If you suspect your hens may have ingested pesticides or been exposed to areas treated with pesticides, discard the eggs for several days to prevent consumption.

\section{What Not to Feed Your Birds}

Watching your flock feed on kitchen scraps can be an enjoyable way to add nutrition to their diet, but too many table scraps can adversely affect growth and egg production. Avoid fatty, salty, sugary, or rotten foods. Never feed the following to your flock:

- Raw green potato peels

- Nightshades such as rhubarb, pepper, potato, eggplant, or tomato leaves

- Raw, dried, or undercooked beans

- Avocado skin and pit

- Candy, chocolate, sugar

- Alcohol and tobacco

(Pitesky and Reimers n.d.)

\section{Poisonous Plants, Weeds, and Other Concerns}

Several commonly used landscape plants and various weeds contain toxins that may be poisonous. Toxins often make 
plants smell or taste bad, and their seeds, in particular, can be toxic. Young animals, especially, may eat these plants out of curiosity. Common symptoms of toxic plant poisoning may include weight loss, diarrhea, lethargy, decreased egg production, and increased mortality. Determining whether your birds have eaten poisonous plants can be difficult because the effects can vary with the amount they have eaten and other factors like temperature. If you remove toxic plants from your yard, don't leave them piled up for your flock to access. Providing enough good food sources, suitable fencing, and space can reduce the risk of your chickens ingesting toxic weeds.

Lists of toxic or poisonous plants are not exhaustive and are not assembled specifically for poultry. Therefore, they can be useful but are unlikely to be complete or conclusive. See Tables 1 and 2 for guidance on poisonous plants and familiarize yourself with poisonous plants at https://www. poison.org/articles/plant. Information on poisonous plants is available at http://sfyl.ifas.ufl.edu/agriculture/ toxic-plants/.

Table 1. Examples of potentially hazardous weeds.

\begin{tabular}{|l|l|}
\hline Scientific Name & Common Name(s) \\
\hline Crotalaria sp. & Rattlebox \\
\hline Cassia obtusifolia & Sicklepod; coffeepod; coffeeweed \\
\hline Cassia occidentalis & Coffee senna \\
\hline Sesbania macrocarpa & Danglepod; hemp sesbania \\
\hline Datura stramonium & $\begin{array}{l}\text { Jimsonweed; angel's trumpet; devil's weed; } \\
\text { thorn apple; tolguacha; Jamestown weed; } \\
\text { stinkweed; datura; moonflower }\end{array}$ \\
\hline Argemone mexicana & Mexican prickly poppy \\
\hline Abrus precatorius & Rosary pea \\
\hline (Damron and Jacob 2001) \\
\hline
\end{tabular}

Table 2. Examples of potentially hazardous landscape plants.

\begin{tabular}{|l|l|}
\hline Scientific Name & Common Name(s) \\
\hline Rhododendron spp. & Azaleas \\
\hline Nerium oleander & Oleander \\
\hline Lantana camara & Lantana \\
\hline Colocasia & Elephant ear \\
\hline Ilex spp. & Holly \\
\hline Caladium & Caladium \\
\hline (Poison Control 2019) & \\
\hline
\end{tabular}

\section{Water}

A constant supply of clean, fresh water is essential for healthy birds. Manufactured chick waterers usually consist of a quart or gallon jar with a screw-on base that allows for water level adjustment. An automatic waterer placed six inches above the ground is the most adequate way to ensure the birds have clean, fresh water daily. Twenty-five hens can drink a gallon of water each day. Expect and encourage a significant increase in water consumption during hot weather. Note that standing water or unlevel, leaking waterers can harbor pests and allow bacterial growth that leads to odors and possibly disease. Maintain clean and dry coop conditions to support the optimal health of your birds.

\section{Egg Production}

Egg production for a small backyard flock should be about 200-240 eggs, or 17-20 dozen, per hen a year. Production will vary based on breed, age, condition of the bird, and day length. Shorter day length may decrease the number of eggs produced because light stimulates egg production. Adding light at the beginning or end of the day to provide 14-16 hours of light per day is effective to maintain egg production throughout the year. A simple clamping light source on a timer can be added inside the coop to increase light exposure, but lights must be turned off for a period of the night to reduce the risk of stress-associated cannibalism.

Note that chickens will also experience a periodic molt in which they lose their feathers and generally decrease laying. This is a natural part of the bird's life cycle and does not indicate a problem. The molt will last for a period of weeks, and your bird will usually return to regular egg production once the molting process is over. Consider that with age your hens will reduce the number of eggs laid; in which case, feed costs may exceed the financial benefit of the eggs produced. Some backyard chicken owners may choose to continue to keep their birds for companionship, while others may look to euthanize and replace those hens with younger, more productive birds.

For more information, see EDIS document PS-35, Factors Affecting Egg Production in Backyard Chicken Flocks (http:// edis.ifas.ufl.edu/ps029).

\section{How many roosters do I need?}

If you have ever wondered how many roosters are required for hens to produce eggs, you are not alone. The general public's distance from food production experience has many suspecting that roosters may be required in order to induce hens to lay eggs, but this is not the case. Roosters are male chickens and are not required in order for female chickens, hens, to lay eggs. When mature, the hen will lay eggs as a regular reproductive function of the body. Roosters are required, however, for fertilized eggs that will later hatch into chicks. 


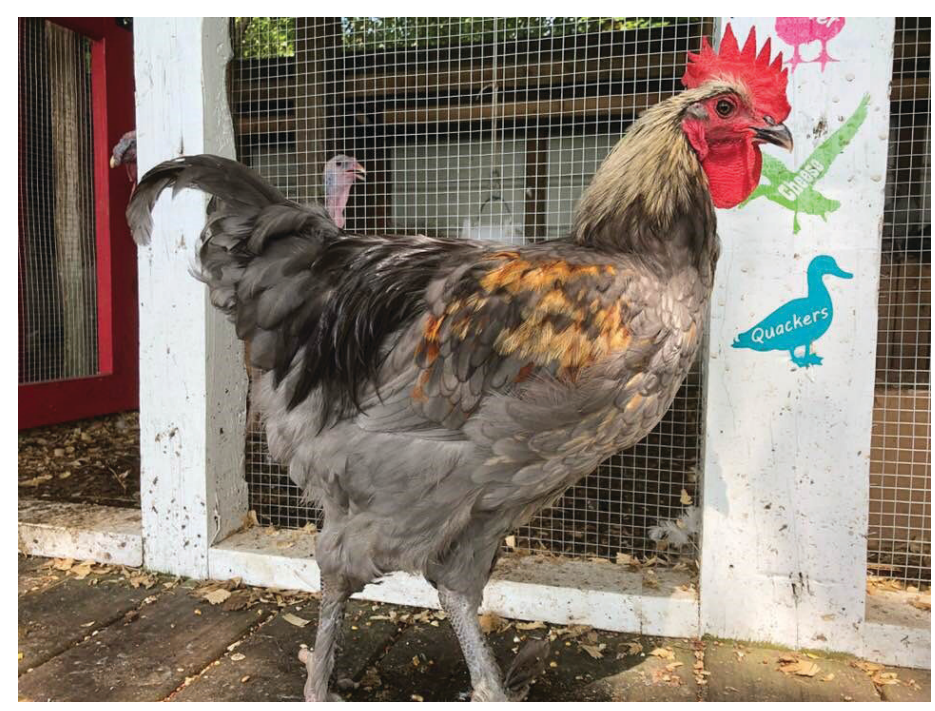

Figure 6. Roosters are not required for hens to lay eggs. Credits: A. Halbritter, UF/IFAS

\section{Collecting and Cleaning Eggs}

Nesting boxes should be checked at least once a day for eggs. Eggs should not be allowed to accumulate in the nests. Otherwise, the hens will go out of egg production and want to sit on the eggs to incubate them. This type of hen is commonly referred to as a "broody" hen. Keep nesting boxes clean to help prevent dirty eggs. The more time the egg spends in the nest, the more likely it is to become dirty, broken, or low quality. Ceramic or wooden eggs can be used to help encourage your hens to use the nesting boxes.

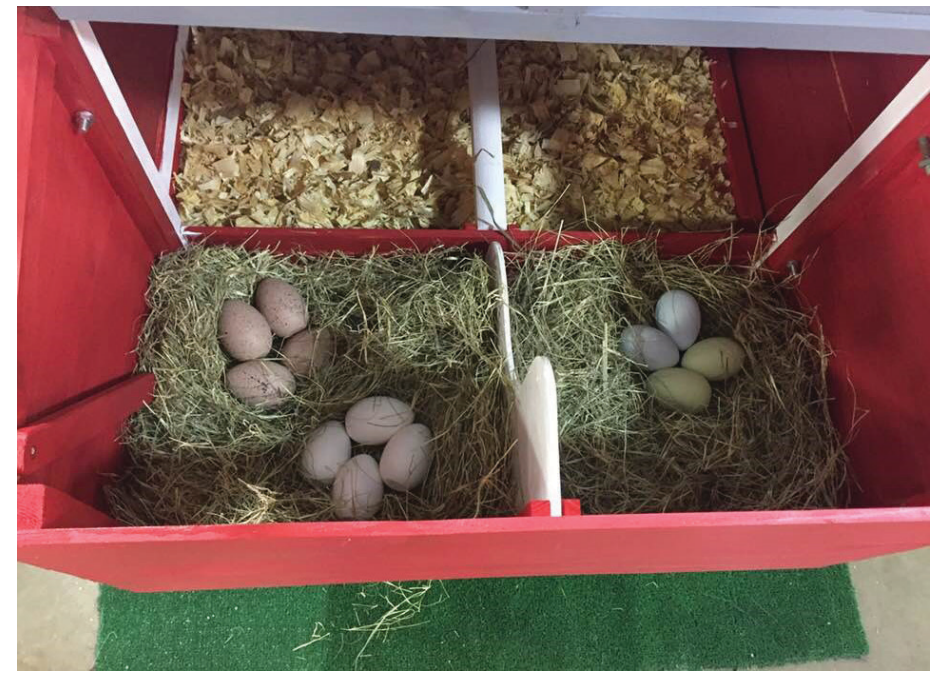

Figure 7. Keep nesting boxes tidy to reduce food safety risks. Credits: A. Halbritter, UF/IFAS

Cleaning and storing eggs is a point of discussion among backyard chicken enthusiasts, and requirements for safe egg handling are inconsistent across states and countries, especially for small numbers of eggs. Understanding the risk of foodborne illness, particularly Salmonella, is important when deciding how to clean your eggs. Use eggs when they are fresh or store them properly. If your eggs are dirty with runny waste droppings on them, this may be an indication of a problem with your birds. Do not use excessively dirty or cracked eggs, since bacterial contamination is possible.

Although eggshells appear solid, they actually contain pores to allow for gas exchange and are covered by a protective mucus, deposited as it is laid, known as the cuticle or "bloom." Differences in opinions on cleaning are related to different production standards, practices, and interpretations of risk priorities. Although eggs may not be washed or refrigerated in other parts of the world, farmers in those areas may also be required to immunize for Salmonella and authorities may consider the risk of condensation during refrigeration worse than the benefits of washing and refrigeration. They may also be required to not use dirty eggs rather than cleaning them. Note that washing and sanitizing eggs are required if you intend to sell eggs under the Limited Poultry Permit, referenced later in this publication.

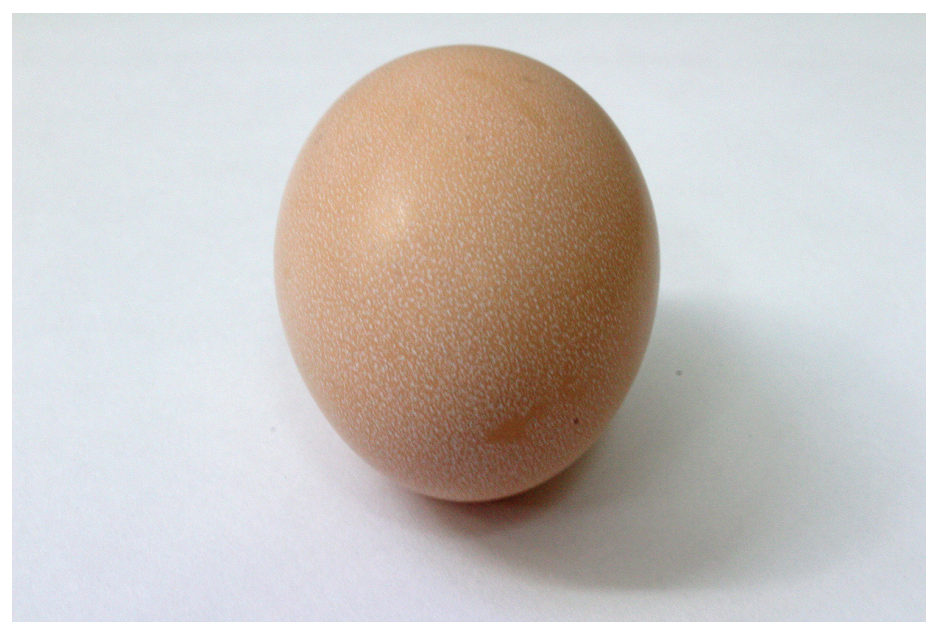

Figure 8. Eggshells contain pores which may allow microbes inside. Credits: A. Halbritter, UF/IFAS

For dry cleaning, a brush or light sanding may be used to remove any dirt or debris. When washing eggs, use water at temperatures of at least $90^{\circ} \mathrm{F}$ and at least $20^{\circ} \mathrm{F}$ warmer than the eggs. Cooler water can create a vacuum, pulling wash water and any microbes it may contain through the shell pores to the inside of the egg. Under high heat conditions, you may need to let eggs cool to room temperature before washing. Avoid immersing the eggs in water and use disposable paper towels to clean each one. Unscented, nonfoaming dish soap may be used for cleaning. When using sanitizers, be sure to follow the directions and note that sanitizers will not be effective if used in dirty water or on dirty eggs. A solution of 1 or 2 tablespoons of bleach to 1 gallon of water can be used as a sanitizer. Once the eggs have been washed, rinsed, and sanitized, they should be dried before being stored in refrigeration at or below 
$45^{\circ} \mathrm{F}$. Eggs should be stored with the larger side up for best quality. If stored properly, refrigerated eggs should have a shelf life of 6 to 8 weeks. Date the storage carton and use older eggs first.

\section{Choosing a Breed}

Worldwide, there are over 400 formally recognized breeds of poultry, each with characteristic personalities, sizes, and intended purposes. Chicken breeds generally fall into one of three categories: laying types, meat-bird types, and dualpurpose, which are kept for both meat and eggs. Breeds that may work well for dual purpose include the Rhode Island Red, Plymouth Rock, New Hampshire, Wyandotte, and Orpington. Dual-purpose birds will consume more food and be larger than laying birds, and therefore may require more space or increase cost of production compared to smaller laying breeds such as the White Leghorn.

Egg-laying breeds will have varied personalities, feather color, size, and egg traits. Some chickens lay white eggs, some lay brown, and some lay blue or green eggs. Eggshell color is based on the breed of the bird and does not affect the nutritional value of the egg. The nutritional value of the egg is a direct product of the nutrition of the bird. Still, brown or colorful eggs may be considered more attractive because they are less common than white. Breed will also determine the number of eggs per year a chicken will lay. Some breeds, like the Golden Comet, produce as many as 300 eggs per year, while others may lay as few as 150 eggs annually. The most common bird used for commercial egg production is the White Leghorn. While the leghorn strain of chicken will produce the most eggs, these birds are quite small and are not a good choice for meat. See characteristics of common backyard breeds in Table 3 .

\section{Mixing Breeds and Ages}

Mixing breeds causes no issues within a chicken flock, and is one of the highlights of owning chickens. Having a variety of breeds that lay eggs of different shapes, sizes, and colors will brighten your egg basket and your coop. Care should be taken if mixing standard size birds and bantam varieties. Bantams are half to a quarter the size of a standard chicken and will lay smaller eggs. It is important to note that chickens do develop a pecking order and introducing new birds to an established flock may disrupt the pecking order. Young birds introduced to a new flock may experience bullying from older hens so it is best for new birds to be introduced slowly over a period of time to reduce the risk of injuries. Introducing new birds at night is a common practice to help reduce conflict in the flock.

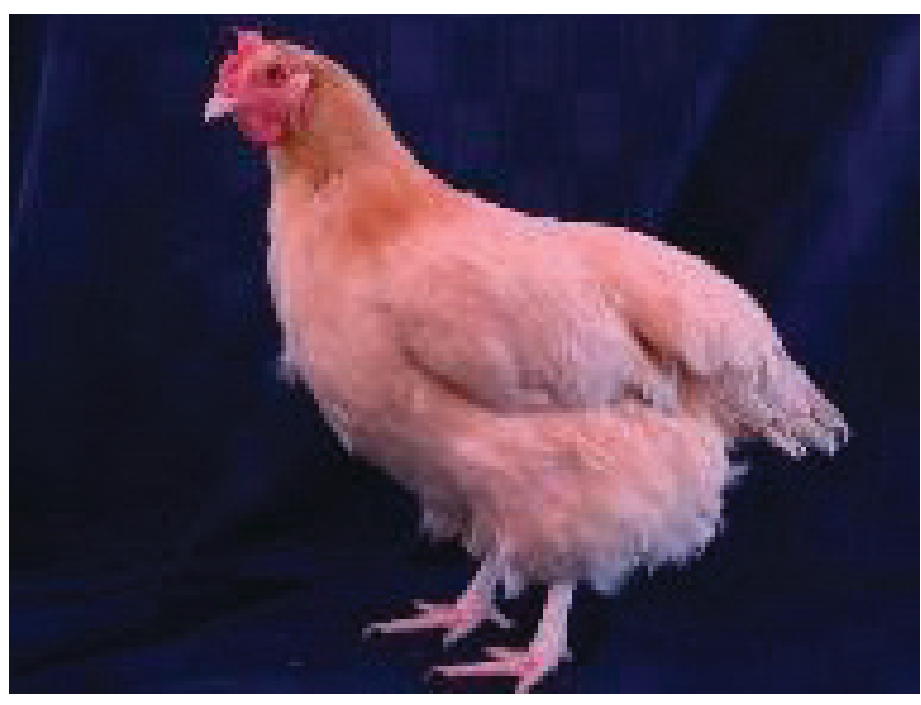

Figure 9. Buff Orpington hen.

Credits: UF/IFAS

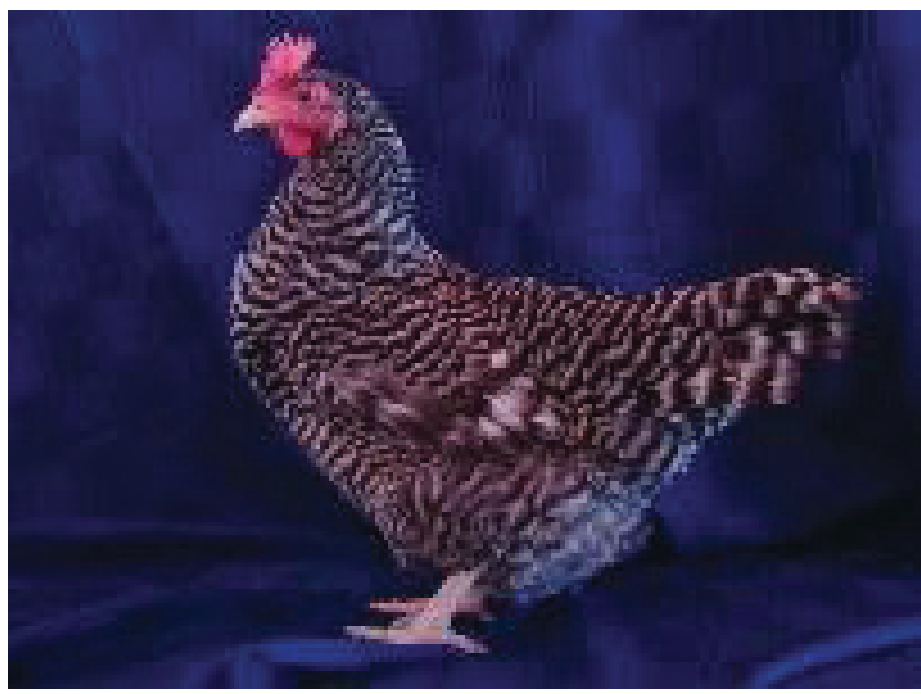

Figure 10. Barred Rock hen

Credits: UF/IFAS

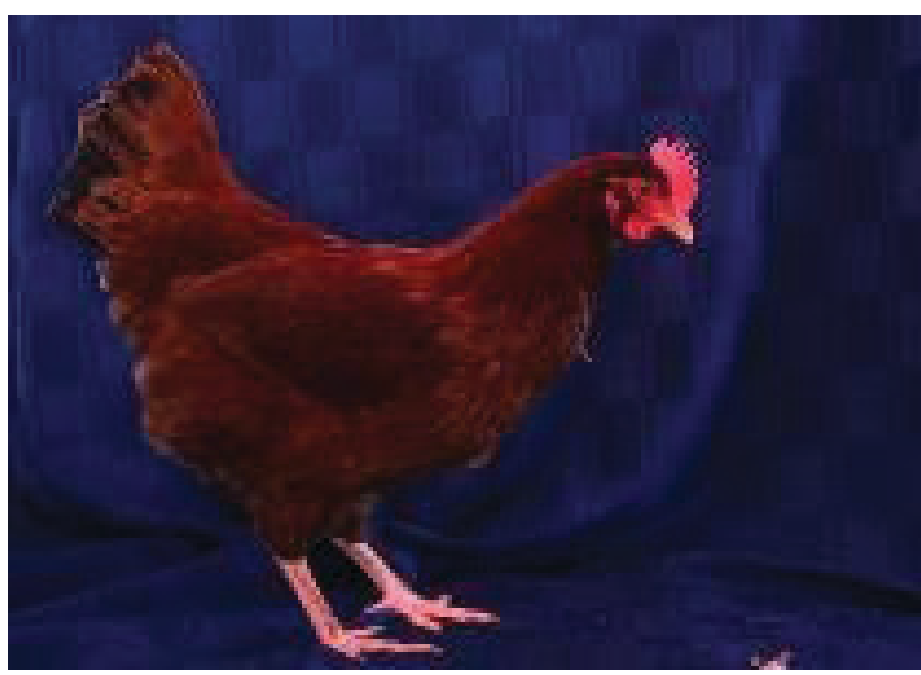

Figure 11. Rhode Island Red hen.

Credits: UF/IFAS 


\section{Purchasing and Caring for Chicks}

Increased interest in backyard chicken production has improved the availability of chicks at many feed stores and rural suppliers, particularly in the spring. Purchasing from your local feed store may help to establish relationships that will help in navigating your project in the future, although chicks may also be ordered directly from national hatcheries. Prepare the area for your chicks before they arrive and consider the extra time required to care for them. Familiarize yourself with common terms to be sure you understand what type of chicks you are purchasing. For example, "pullets" are females that have not yet sexually matured to lay eggs. "Straight run" indicates that the chicks have not been separated into male and female groups, which means the group will include about $50 \%$ male chicks or future roosters.

\section{Brooding}

Newly hatched chicks need a heat source the first few weeks of life. The most common way to brood a small flock (25-50 chicks) is with a heat lamp. The 250-watt heat lamp should be placed 12-18 inches above the chicks. Day-old chicks need a temperature of $90^{\circ} \mathrm{F}-95^{\circ} \mathrm{F}$. The behavior of the chicks is a good indicator of their comfort. If the chicks are huddled close to the heat source, they are cold; if they stay away from the heat source, they are too hot. Quiet, evenly distributed chicks are a sign of optimum temperature. A thermometer is the most accurate way to keep track of the temperature. Be sure the height of the thermometer is at the same height as the chicks for an accurate temperature reading at "chick level." The temperature should be lowered by $5^{\circ} \mathrm{F}$ per week until the chicks are four weeks old or have feathered. Adjust the height of the lamp to adjust the temperature. Raising the lamp a few inches each week should drop the temperature by $5^{\circ} \mathrm{F}$. Heat lamps may also be used with adult birds during frigid weather to reduce the impacts of cold stress. For more information on the care of baby chicks, see EDIS document AN-170, Care of Baby Chicks (http://edis.ifas.ufl.edu/an182).

\section{Examples of National Hatcheries}

\section{Murray McMurray}

PO Box 458

191 Closz Drive

Webster City, Iowa 50595

(800) 456-3280

http://www.mcmurrayhatchery.com/index.html
Ideal Poultry Breeding Farms Inc.

PO Box 591

Cameron, Texas 76520-0591

(254) 697-6677

http://www.ideal-poultry.com/

Mt. Healthy Hatcheries Inc.

9839 Winton Road

Mt. Healthy, Ohio 45231

(800) 451-5603

http://www.mthealthy.com/

\section{Cackle Hatchery}

PO Box 529

Lebanon, Missouri 65536

(417) 532-4581

http://www.cacklehatchery.com

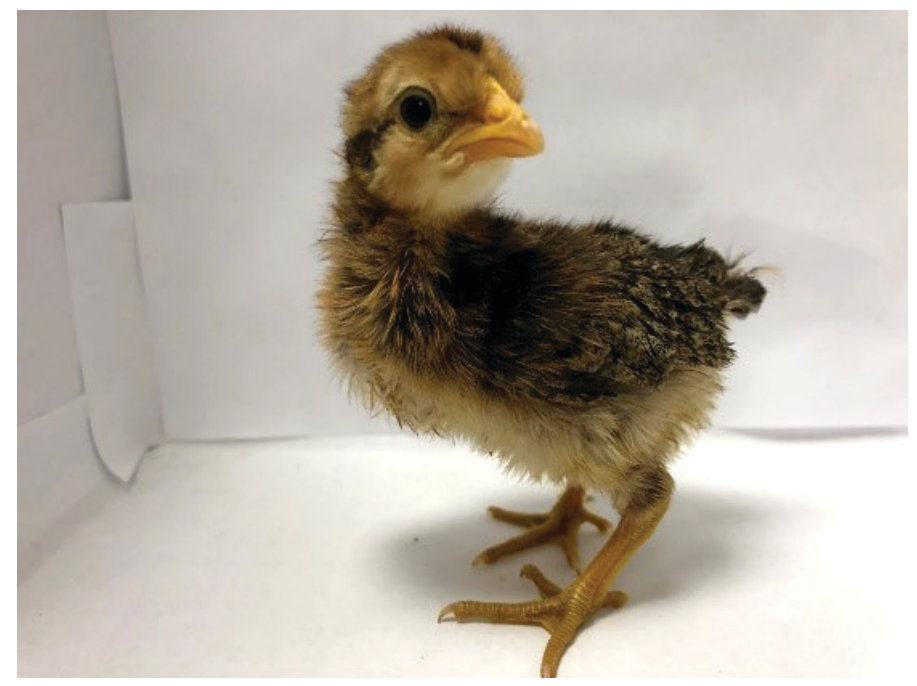

Figure 12. Chicks need warm conditions and protection from drafts until they are fully feathered.

Credits: A. Halbritter, UF/IFAS

\section{Cleaning and Composting}

Maintaining clean and dry conditions inside the coop will require time, effort, and regular replacement of bedding. Clean nesting boxes once a week and replace soiled litter with clean nesting material. Thoroughly clean and disinfect the entire coop at least once a year using approved disinfectants available at feed stores. Be sure to follow the labeled instructions.

Composted chicken manure can be an excellent fertilizer material because it contains essential plant nutrients and can improve soil structure, but manure should be composted to proper temperatures and prepared in specific ways to kill harmful bacteria before being used on fruits, vegetables, and ornamentals. According to National Organic Program Standards, composting to $131-170^{\circ} \mathrm{F}$ 
will ensure pathogens and weed seeds are destroyed. The length of time this temperature must be maintained varies based on the composting method. Aerated or contained piles must maintain at least $131^{\circ} \mathrm{F}$ for three days. Standards for windrow compost piles, which are less likely used on the homeowner scale, require maintaining temperatures between 131 and $170^{\circ} \mathrm{F}$ for 15 days and turning the pile at least five times during that period. If the compost pile has not been closely monitored to verify the temperature has reached at least $131^{\circ} \mathrm{F}$, consider the potential risk of pathogens and reduce risks by using the compost on ornamentals rather than food plants.

\section{“Give a hoot. Don't pollute."}

Do not store waste or compost in proximity to water bodies, and consider the effect of runoff from your coop. Chicken manure is rich in nitrogen and phosphorous, nutrients that can lead to excessive plant and algae growth in water. As microbes decompose the increased organic matter, they can deplete the available oxygen in the water, leading to fish kills. Florida has many water bodies considered impaired due to excessive nutrients. Runoff containing waste from your chickens can contribute to pollution, so it is generally a good idea to keep your flock housing or composting bins at least 50 feet away from any water body. Chicken manure can also be bagged and sent to the landfill with general household trash. Check with your county/city on disposal policies.

For composting methods, read "Composting and Using Backyard Chicken Poultry Waste in the Home Garden": https://www.cals.uidaho.edu/edcomm/pdf/CIS/CIS1194. pdf.

\section{Dealing with Mortality}

Whether by predators or natural aging, backyard enthusiasts should be prepared for dealing with the mortality of their birds. Some backyard flocks may experience 10\% mortality or higher; however, good management may reduce mortality. When the time comes, disposal options include burying, landfill disposal, or composting your birds. Consider the burial location and the potential for animals to find and dig up your birds. Bury two feet deep, as per Florida Statute 823.041. Check with your city or county regarding sending your birds to landfill with household trash. A generally recommended practice is to double bag before disposal. Composting is not recommended in residential areas. Also note that slaughtering is generally prohibited under ordinances pertaining to residential areas. Check your local city/county codes about mortality management.

\section{Biosecurity}

As a backyard chicken owner, you may be unaware of the risks of introducing or contracting disease from other birds or natural sources. In recent years, periodic detection of Avian Flu and other risk factors has occurred. Observation is the key to managing health of your flock. Make note of normal appearance and behavior, activity patterns, and facility conditions. Deviations from normal are early indicators that something may be wrong and may allow an early response. Understand that pets, wild animals including birds, mosquitoes, and even visitors to your backyard may be a source of inoculum.

If you suspect disease in your flock, contact your local county Extension office for guidance. The Florida Department of Agriculture and Consumer Services (FDACS) monitors disease detections and offers diagnostic tests for a fee via the Bronson Animal Disease Diagnostic Laboratory. Your local health department may also be of assistance. Find out more about poultry diseases, including those transmissible to humans, at https://edis.ifas.ufl.edu/topic_ poultry_diseases. Check for FDACS animal disease updates at https://www.freshfromflorida.com/Consumer-Resources/ Animals/Animal-Disease-Information.

Disease is generally less common in small flocks due to lower density and contamination. As previously mentioned, vaccinations are available for some poultry diseases and chicks may be purchased already vaccinated for some diseases, such as Marek's disease. Some online poultry supply sources offer vaccination supplies for diseases such as Fowl Pox, but they are often sold in larger quantities than needed for backyard flocks and generally require careful attention to storage, mixing, and application instructions.

\section{Love with Limits}

The Centers for Disease Control has noted an uptick in human illness and even death due to contact with backyard chickens. These cases have often involved excessive displays of affection or other inappropriate handling of chickens, especially by children. Be aware that chickens may have pathogens in their droppings and on their bodies (feathers, feet, and beaks) even when they appear healthy and clean. Always wash hands with soap and water right after touching live poultry or areas where they live and roam. Adults should supervise handwashing for young children. Do not let live poultry inside the house, in bathrooms, or especially 
in areas where food or drink is prepared, served, or stored. Be sure to thoroughly cook any eggs collected from your hens. Stay outdoors when cleaning any equipment or materials used to raise or care for live poultry, such as cages or feed or water containers. Buy birds from hatcheries that participate in the US Department of Agriculture National Poultry Improvement Plan (USDA-NPIP) to reduce risk of disease.

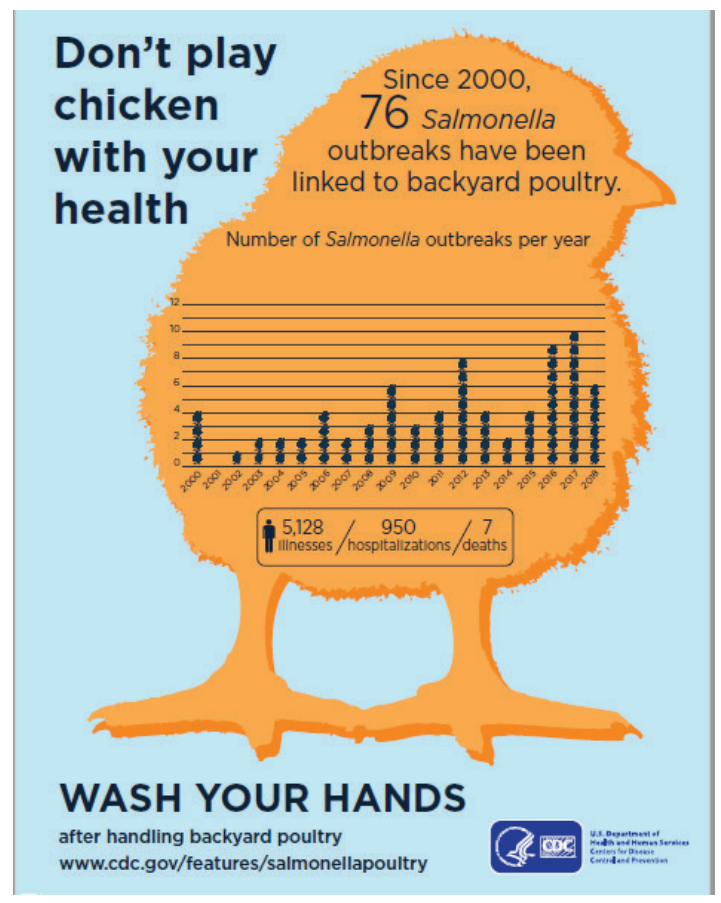

Figure 13. Chickens may carry Salmonella, which has led to illness and deaths in recent years.

Credits: CDC

\section{Limited Poultry Permit}

Did you know that Florida's farming population is approaching retirement? Beginning farmers are needed to ensure access to locally grown food. Those thinking of taking it to the next level and producing eggs or meat for sale should be aware of the Florida Department of Agriculture and Consumer Services (FDACS) Limited Poultry Permit. This permit allows for sale of eggs and "dressed poultry" in limited quantities within Florida. The permit allows sale to individuals as well as restaurants and institutions, but does not allow wholesale sales. Find out more about the FDACS permit and requirements at https://www.freshfromflorida. com/Business-Services/Food-Establishment-Inspections/ Limited-Poultry-and-Egg-Farms.

\section{Additional Resources}

UF/IFAS Extension Small Farms and Alternative Enterprises website: https://smallfarm.ifas.ufl.edu/production/ livestock-and-forages/

UF/IFAS Extension EDIS Publications on Poultry Management: http://edis.ifas.ufl.edu/topic_poultry_management

eXtension Small and Backyard Flocks: https://articles. extension.org/poultry

OMRI (Organic Materials Review Institute) Guidance on Egg Cleaners and Sanitizers: https://www.omri.org/ egg-cleaners-and-sanitizers

USDA, Food Safety and Inspection Service, Guidance for Shell Egg Cleaners and Sanitizers: https://www.fsis.usda. gov/wps/portal/fsis/topics/regulatory-compliance/labeling/nonfood-compounds/shell-egg-cleaners-sanitizers/ guidance-shell-egg-cleaners-sanitizers

Electronic Code of Federal Regulation Part 590-Inspection of Eggs and Egg Products: https://ecfr.io/Title-09/ se9.2.590_1515

\section{References}

Burbaugh, B., E. Toro, and A. Gernat. 2010. Introduction to Pasture-Raised Poultry: Maximizing Foraging Behavior. AN237. Gainesville: University of Florida Institute of Food and Agricultural Sciences. https://ufdcimages.uflib.ufl.edu/ IR/00/00/37/72/00001/AN23700.pdf

Cornell Small Farms Program. 2014. "Cleaning and Disinfecting Your Poultry House." Accessed April 3, 2019. https://smallfarms.cornell.edu/2014/04/07/ cleaning-and-disinfecting-your-poultry-house

Damron, B. L., and J. P. Jacob. 2001. Toxicity to Poultry of Common Weed Seeds. PS-55. Gainesville: University of Florida Institute of Food and Agricultural Sciences. http:// ufdcimages.uflib.ufl.edu/IR/00/00/30/36/00001/PS05200. pdf

Davis, M. A. 2015. Small Flock Poultry Nutrition. PS29. Gainesville: University of Florida Institute of Food and Agricultural Sciences. http://edis.ifas.ufl.edu/ps033 
e-CFR. 2000. “7 C.F.R. $\$ 205.2 .2000$ 'National Organic Program Rule (United States Department of Agriculture [USDA])."' Accessed April 3, 2019. https://www.ecfr.gov/ cgi-bin/text-idx?c=ecfr\&sid=3f34f4c22f9aa8e6d9864cc2683 cea02\&tpl=/ecfrbrowse/Title07/7cfr205_main_02.tpl

eXtension. 2019. "Small and Backyard Flocks." Accessed April 3, 2019. https://articles.extension.org/poultry

F.S. 823.041. 2018. "Disposal of Bodies of Dead Animals; Penalty." Accessed April 4, 2019. http://www.leg.state.fl.us/ statutes/index.cfm?App_mode=Display_Statute\&Search_ String $=\& U R L=0800-0899 / 0823 /$ Sections/0823.041.html

Griggs, J. P., and J. P. Jacob. 2005. Alternatives to Antibiotics for Organic Poultry Production Department of Animal Science. University of Minnesota, St. Paul, Minnesota: Poultry Science Association, Inc.

Jacob, J. P., H. R. Wilson, R. D. Miles, G. D. Butcher, and F. Ben Mather. 2017. Factors Affecting Egg Production in Backyard Chicken Flocks. PS-35. Gainesville: University of Florida Institute of Food and Agricultural Sciences. http:// edis.ifas.ufl.edu/ps029

Maryland Cooperative Extension. n.d. "Composting Animal Mortalities on the Farm." Accessed April 3, 2019. http://extension.umd.edu//sites/extension.umd.edu/ files/_docs/Composting\%20Animal\%20Mortalities\%20 on\%20the\%20farmFS717.pdf

Merck Veterinary Manual. 2019. “Overview of Coccidiosis in Poultry.” Accessed April 16, 2019. https:// www.merckvetmanual.com/poultry/coccidiosis/ overview-of-coccidiosis-in-poultry

NC Cooperative Extension Carteret County Center. 1980. "Poisonous Plants of the Southern United States." Accessed April 3, 2019. https://carteret.ces.ncsu.edu/wp-content/ uploads/2013/05/Poisonour-Plants-of-the-SouthernUnited-States.pdf?fwd $=$ no

Penn State Extension. 2016. "Poultry Cannibalism: Prevention and Treatment." Accessed April 3, 2019. https://extension.psu.edu/ poultry-cannibalism-prevention-and-treatment

Pitesky, M., and N. Reimers. n.d. "Feeding Your Flock." Accessed April 3, 2019. https://ucanr.edu/sites/poultry/ files/201398.pdf
Poison Control. 2019. "Poisonous and Non-Poisonous Plants: An Illustrated List.” Accessed April 12, 2019. https:// www.poison.org/articles/plant

University of Idaho Extension. 2013. "Composting and Using Backyard Poultry Waste in the Home Garden." Accessed April 3, 2019. https://www.cals.uidaho.edu/edcomm/pdf/ CIS/CIS1194.pdf

University of Illinois at Urbana-Champaign. 2015. "Composting to Reduce Weed Seeds and Plant Pathogens." Accessed April 3, 2019. https://articles.extension.org/pages/28585/ composting-to-reduce-weed-seeds-and-plant-pathogens

University of Missouri Extension. 2011. "Housing \& Space Requirements.” Accessed April 16, 2019. https://extension. tennessee.edu/McMinn/4H/Backyard\%20Chickens\%20 Information\%20Publication.pdf

University of Wisconsin-Madison and University of Wisconsin-Extension. 2010. "Egg Safety and the Backyard Flock.” Accessed April 3, 2019. https://foodsafety.wisc.edu/ assets/pdf_Files/Egg_Safety_and_the_Backyard_Flock.pdf 
Table 3. Description of selected backyard chicken breeds.

\begin{tabular}{|c|c|c|c|c|}
\hline Breed & Plumage Color & $\begin{array}{l}\text { Eggshell } \\
\text { Color }\end{array}$ & Rate of Lay & Breed Information \\
\hline Barred Plymouth Rock & Black and white barring & Brown & Excellent & Old breed; excellent dual-purpose breed \\
\hline Black Sex-Link & $\begin{array}{l}\text { Black with gold hackle and } \\
\text { breast }\end{array}$ & Brown & Excellent & $\begin{array}{l}\text { Cross of Rhode Island Red and Barred Plymouth } \\
\text { Rock }\end{array}$ \\
\hline Brown Sex-Link & $\begin{array}{l}\text { Dark red with black tails and } \\
\text { wings }\end{array}$ & Brown & Excellent & Cross of Rhode Island Red and White Plymouth Rock \\
\hline Gold Sex-Link & $\begin{array}{l}\text { Light red with white tails and } \\
\text { wings }\end{array}$ & Brown & Excellent & Cross of Rhode Island Red and Rhode Island Whites \\
\hline Red Sex-Link & $\begin{array}{l}\text { Dark red with black tails and } \\
\text { wings }\end{array}$ & Brown & Excellent & Cross of Rhode Island Red and Delaware \\
\hline Rhode Island Red & Very dark red & Brown & Excellent & Old breed; popular dual-purpose \\
\hline Black Australorp & Black with greenish sheen & Brown & Excellent & Excellent small-flock producer; hardy \\
\hline Easter Egger & $\begin{array}{l}\text { Multicolored (white, brown, } \\
\text { red, black) }\end{array}$ & $\begin{array}{l}\text { Green, blue, } \\
\text { light brown }\end{array}$ & Excellent & $\begin{array}{l}\text { Nicknamed "Easter Egg Chicken" due to color of } \\
\text { eggshell; hybrid, not a pure breed }\end{array}$ \\
\hline White Leghorn & White & White & Excellent & $\begin{array}{l}\text { Excellent layer; most common commercial US egg } \\
\text { industry breed }\end{array}$ \\
\hline New Hampshire Red & Chestnut red & Brown & Very good & Popular dual-purpose breed; grows fast \\
\hline Silver Laced Wyandotte & $\begin{array}{l}\text { Silvery white; edged with } \\
\text { black }\end{array}$ & Brown & Very good & Beautiful old breed; popular for cold areas \\
\hline White Plymouth Rock & White & Brown & Very good & Medium-sized dual-purpose breed \\
\hline Golden Laced Wyandotte & $\begin{array}{l}\text { Golden; edged with greenish } \\
\text { black }\end{array}$ & Brown & Good & Same as Silver Laced \\
\hline Buff Orpington & Rich golden buff & Brown & Good & $\begin{array}{l}\text { Large breed with quiet disposition; popular } \\
\text { backyard flock }\end{array}$ \\
\hline
\end{tabular}

